\title{
ORGANIC CARBON AND SOIL FERTILITY IN THE TEMPERATE FOREST OF THE HUEYAPA RIVER MICROWATERSHED, GUERRERO, MEXICO
}

\author{
NAVARRO-MARTÍNEZ JOSÉ ${ }^{1}$, LÓPEZ-LÓPEZ MIGUEL ÁNGEL ${ }^{2}$, GODINEZ-JAIMES \\ FLAVIANO ${ }^{3}$, ROSAS-ACEVEDO JOSÉ LUIS ${ }^{4}$, JUÁREZ-LÓPEZ ANA LAURA ${ }^{4}$ AND REYES- \\ UMAÑA MAXIMINO*4
}

\begin{abstract}
${ }^{1}$ Unidad de Educación Media Superior Tecnológica Agropecuaria y Ciencias del Mar (UEMSTAyCM). Calle Rubén Mora S/N, Col. Guerrero 200, Chilpancingo de los Bravo, Guerrero, México. CP. 39097. ${ }^{2}$ Forest Sciences Program, Colegio de Postgraduados. Km. 36.5 Carr. México-Texcoco, Col. Montecillo, Texcoco, Estado de México, México. CP 56230. ${ }^{3}$ Faculty of Mathematics, Universidad Autónoma de Guerrero (UAGro). Av. Lázaro Cárdenas S/N, Ciudad Universitaria Sur, Chilpancingo de Los Bravo, Guerrero, México. CP 39087. ${ }^{4}$ Centro de Ciencias de Desarrollo Regional (CCDR), UAGro. Calle Privada del Laurel No. 13, Col. El Roble, Acapulco de Juárez, Guerrero, México. CP. 39640.
\end{abstract}

*Corresponding author: maxis_99@hotmail.com

Submitted final draft: 16 May $2020 \quad$ Accepted: 2 June 2020

http://doi.org/10.46754/jssm.2020.12.014

\begin{abstract}
Forest soils play an important role in mitigating global warming, as they constitute important reservoirs of organic carbon as a result of vegetation cover. This study was carried out to estimate the soil organic carbon (SOC) reservoir and the forest soil fertility of the microwatershed of the Hueyapa River, located in the State of Guerrero, Mexico, in relation to tree density and basal area. Dasometric variables were estimated using the INFyS methodology of Mexico and SOC was estimated at a depth of 0 to 30 $\mathrm{cm}$. The soil organic carbon concentration was determined by the Walkley-Black method. Fertility was determined according to NOM-021-SEMARNAT-2000. A multiple linear regression model was developed to relate SOC with tree density $(T D)$ and basal area $(B A)$. The temperate forest of the Hueyapa River microwatershed showed a TD of 397 trees $^{-1}$ and a $B A$ of $22.882 \mathrm{~m}^{2} \mathrm{~h}^{-1}$. The average SOC reservoir was $65.52 \mathrm{Mg} \mathrm{ha}^{-1}$. According to the statistical model developed, $T D$ and $B A$ explained $37 \%$ of the SOC variability. The correlation between the observed SOC and the estimated SOC whit the fitted regression model was 0.61 . Soil $\mathrm{pH}$ is strongly acidic, with a high content of soil organic matter (SOM), low cation exchange capacity (CEC), low availability of nitrogen $(\mathrm{N})$, medium availability of phosphorus $(\mathrm{P})$, and adequate concentrations of iron $(\mathrm{Fe})$, copper $(\mathrm{Cu})$, zinc $(\mathrm{Zn})$, and manganese $(\mathrm{Mn})$. The observed adequate distribution of microelements agreed with vegetation uniformity and tree, shrub and herb vigor, throughout the study area.
\end{abstract}

Keywords: SOC, soil fertility, forest soil.

\section{Introduction}

Monitoring carbon sequestration in forest ecosystems is essential for global warming mitigation projects. Forest soils are important reservoirs of organic carbon, in the form of humidified organic matter, which is associated to the physiognomy of the vegetation cover (Stendahl et al., 2010; Rodríguez et al., 2017), environmental factors, toponymy, soil depth (Avilés-Hernández et al., 2009), quantity and type of plant production and the process of mineralization of litter (Coûteaux et al., 1995).

SOM is made up of organic components at various stages of decomposition such as plant tissues, soil organisms and dead animals smaller than two millimeters (Post \& Kwon, 2000). SOM contains less carbon in deep layers than in upper layers (Bianchi et al., 2008). In general, SOC comprises $50 \%$ to $58 \%$ of the SOM (Pribyl, 2010).

The heterogeneity of the SOC reservoir depends on the type of soil and parental material (Angst et al., 2018), climate, relief, type of vegetation (Galicia et al., 2016) and the age of the forest site (Casiano-Domínguez et al., 2018). Statistical models allow estimation of SOC from soil depth (Paz \& Etchevers, 2016), root biomass, the proportion of clay and the fraction of particulate organic matter (Angst et al., 2018). Covaleda et al. (2013) state that, in 
stable ecosystems, it is possible to parameterize a significant statistical linear correlation between the aboveground biomass and SOC; however, there are no models that consider tree density or basal area per hectare for SOC prediction.

The organic carbon stock in the aboveground biotic component is approximately one third that of the mineral soil at one meter of depth (Food Agriculture Organization [FAO], 2017), but its distribution is spatially and temporarily variable; however, within the first $30 \mathrm{~cm}$ depth, the organic carbon content presents greater stability (Alvarado et al., 2013; Monreal et al., 2005). This depth is recommended by the IPCC to carry out the inventory of the SOC (Intergovernmental Panel on Climate Change [IPCC], 2006).

The worldwide reservoir of organic carbon in forest soil is approximately $44 \%$ of the world's estimated land area; this fluctuates between $383 \mathrm{Pg}$ and 2,000 Pg (Jansen, 2004; Pan et al., 2011). For Mexican forest soils the SOC reservoir is $9 \mathrm{Pg}$ at a depth of 0 to $30 \mathrm{~cm}$ (Etchevers-Barra et al., 2019).

The productivity of forest ecosystems is influenced by climatic, edaphic conditions, the structure of (forest) stands (Legout et al., 2014; Salcedo-Pérez et al., 2018) and stands age (Thongjoo et al., 2018), which regulate the nutrient cycles and their reservoirs. Likewise, the stable fraction of the SOC contributes mainly to the nutrient retention capacity and, since such fraction decomposes very slowly, it is important for long-term carbon sequestration (FAO, 2017).

In particular, the physical characteristics of the soil have a strong impact onto the dynamics and structure of forests (Pan et al., 2013). pH determines the availability of nutrients for the vegetation, and in other cases, some nutrients are the limiting factors for the development of roots, as it is the case of the available phosphorus (Quinto et al., 2016). In general, the availability of nutrients in the soil is closely related to the spatial distribution of vegetation (Soares da Silva et al., 2017).
Currently, there is no SOC information in forests dominated by Pinus oocarpa Schiede (ocote) and Quercus spp. (encino), in the State of Guerrero, Mexico. Therefore, the present study was carried out to estimate this reservoir and its fertility in relation to tree density and basal area per hectare in the temperate forest of the microwatershed of the Hueyapa River, Guerrero, Mexico.

\section{Materials and Methods}

\section{Study Area}

The study area corresponded to the temperate forest (pine-oak) of the microwatershed of the Hueyapa River, located between the North latitude geographic coordinates of $17^{\circ} 10^{\prime} 33^{\prime \prime}$ and $17^{\circ} 17^{\prime} 44^{\prime \prime}$ and West longitude of $99^{\circ} 26^{\prime} 28^{\prime \prime}$ and $99^{\circ} 31^{\prime} 12^{\prime \prime}$. It belongs to the Omitlán River Sub-watershed (RH20Eb), Papagayo River Watershed (RH20E), of the 20 Hydrological Region, in the Costa Chica de Guerrero (Figure 1). It is bounded by the municipalities of Juan R. Escudero and Chilpancingo de los Bravo, in the central zone of the State of Guerrero, Mexico (Instituto Nacional de Estadística y Geografía [INEGI], 2010).

The microwatershed has a total area of 7 488.55 ha, with $48 \%$ covered by temperate oak and pine-oak forest, distributed between 600 and 1,613 meters above sea level, with an undulating to steeply slope. It has a warm sub-humid Aw(1) $\mathrm{w}$ climate with a mean annual temperature of $24^{\circ} \mathrm{C}$, rains in summer with rainfall fluctuating between $1300 \mathrm{~mm}$ and 2,000 $\mathrm{mm}$ per year (Navarro-Martínez et al., 2019).

\section{Methodology}

The spatial variability of the forest makes the stratified sampling the most convenient (Andrade \& Ibrahim, 2003) therefore, the forest area of the temperate forest of the Hueyapa River microwatershed $(2,761.9$ ha) was stratified into pine-oak forest (P-Q) and oak forest (Q) with 1 601.8 ha and 1160.1 ha, respectively.

The sampling design used was random stratified combined with cluster (Comisión 


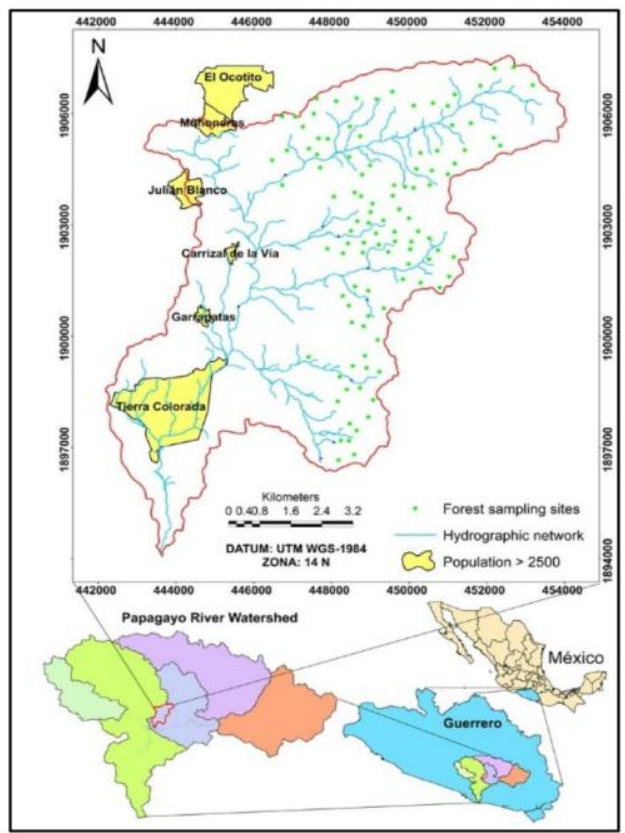

Figure 1: Study area

Nacional Forestal - Secretaría de Medio Ambiente y Recursos Naturales [CONAFORSEMARNAT], 2011). At the center of each primary sampling unit (PSU), a 0-30 $\mathrm{cm}$ mineral soil sample was obtained to measure the SOC. The population was split into 33 strata or basic forest management units (stands) with 16 of them being $\mathrm{P}-\mathrm{Q}$ and $17 \mathrm{Q}$. The total number of PSU was 2,266 with 1,442 being P-Q. The sample size was obtained as part of a related investigation in which the aboveground biomass in the study area was estimated. A pilot sampling was first performed to obtain the sample means and variances in some stands. Subsequently, stratified sampling was used with proportional allocation to the size of the stratum, considering the accuracy of $1 \mathrm{Mg} \mathrm{ha}^{-1}$ of aboveground biomass and $95 \%$ reliability (Scheaffer et al., 1987). Thereafter the PSU's were randomly selected on each stratum. The sample size of the forest inventory for the temperate forest ecosystem was 105 PSU; 57 PSU for the P-Q stratum, and 48 PSU for the Q stratum. Ratio estimators were used for the SOC total and mean population with auxiliary information given by the study area according to the methodology proposed by Velasco et al. (2003) in the National Forest and Soil Inventory.

The SOC analysis was carried out by integrating samples composed by stand, for both strata of vegetation and the calculation of the organic carbon content in the soil was performed with Equation 1 (Andrade \& Ibrahim, 2003).

The SOC estimation was made by integrating samples composed by stand, for both strata of vegetation, under the methodology of Paz et al. (2016) applying Equation 1. The bulk density $(B d)$ was obtained by using a 30 cm depth cylinder method, applying Equation 2 (Andrade and Ibrahim, 2003).

$$
\begin{aligned}
& S O C=(B d)(D)\left(1-\frac{C F}{100}\right)(S O C p)(100) \\
& B d=\left(\frac{D w s}{C v}\right)
\end{aligned}
$$


where SOC is the soil organic carbon $\left(\mathrm{Mg} \mathrm{ha}^{-}\right.$ $\left.{ }^{1}\right), D$ is the sampling depth (m), $C F$ is the percentage of coarse fragments of the mineral soil (> $2 \mathrm{~mm}), \mathrm{SOC} p$ the percentage of soil carbon determined in the laboratory and 100 is a unit conversion factor. Dws is the dry weight of the soil, and $C v$ is the cylinder volume $\left(\mathrm{cm}^{3}\right)$.

The concentration of soil organic carbon (\% CO) was determined by the Walkley-Black method (Allison, 1965; McLeod, 1973) in the plant nutrition laboratory "Dr. Salvador Alcalde Blanco" of Colegio de Postgraduados, Mexico. $B d$ was obtained for each PSU by the cylinder method of known volume; the soil samples were transferred to the Biomonitoreo y Control Biológico (Biomonitoring and Biological Control) Laboratory of the CCDR-UAGro, for oven drying at $100^{\circ} \mathrm{C}$, until constant weight, as established by Andrade and Ibrahim (2003).

Tree density, basal area and SOC per stand, per strata and for total temperate forest of the microwatershed, were estimated using the methodologies proposed by Velasco et al., (2003) for the National Forest and Soils' Inventory of Mexico.

A composite soil sample was made from each of the ten main aspect-defined stands found along both vegetation strata. Thereafter, soil $\mathrm{pH}$ and organic matter content were determined (Walkley \& Black, 1934; Kalra \& Maynard, 1991), as well as the fertility indicators: CEC, total $\mathrm{N}, \mathrm{P}, \mathrm{K}, \mathrm{Ca}, \mathrm{Mg}, \mathrm{Fe}, \mathrm{Cu}, \mathrm{Zn}, \mathrm{Mn}$ and $\mathrm{B}$ (Berger \& Truog, 1944; Diario Oficial de la Federación [Official Journal of the Federation] [D. O. F.], 2002; González et al., 2009).

Means difference between the vegetation strata in terms of the tree density (TD), that is the number of trees per hectare, basal area (BA) in $\mathrm{m}^{2}$ per hectare, apparent soil density, SOCp, and SOC, was determined by the Student's t-test for independent samples (Ross, 2005).

A multiple regression model (equation 3) was adjusted to estimate the SOC as a function of tree density, basal area and type of vegetation. Variables were selected using the Akaike information criterion (AIC) method (Venables \& Ripley 2002).

$$
\mathrm{SOC}=\beta_{0}+\beta_{1} T D_{i}+\beta_{2} B A_{i}+\beta_{3}\left(T D_{i} * B A_{i}\right)+\varepsilon_{i}
$$

where:

SOC $=$ soil organic carbon $\left(\mathrm{Mg} \mathrm{ha}^{-1}\right)$

$T D=$ tree density $\left(\#\right.$ trees $\left.\mathrm{ha}^{-1}\right)$

$B A=$ basal area $\left(\mathrm{m}^{2} \mathrm{ha}^{-1}\right)$

The model assumes, that is, errors have normal distribution, are independent and have constant variance. Compliance with the normal distribution was evaluated with the ShapiroWilk's test implemented in the shapiro.test function of the nortest package (Gross \& Ligges, 2015) and the homogeneity of variance with the non-constant variance test performed with the ncvTest function of the car package (Fox \& Weisberg, 2011).

The model fitting and assessment of the compliance of the assumptions were made by using the statistical package $\mathrm{R}$ ( $\mathrm{R}$ Core Team, 2016). The predictive capacity of the model was measured with the root of the mean of the sum of squared residuals (RMSR) and the correlation $\left(r^{2}\right)$ between the observed SOC and the estimated SOC (Fox, 2016).

\section{Results and Discussion}

\section{Dasometric estimations in the temperate forest of the Hueyapa River microwatershed}

The total land surface of the temperate forest of the Hueyapa River microwatershed is 3,442.6 ha, out of which $2,761.9$ ha are covered by pineoak and oak forests. The pine-oak forest covers an area of 1,601.8 ha and the oak forest covers $1,160.1$ ha. The temperate forest tree vegetation is composed of six Quercus species $(Q$. resinosa Liebm., Q. crispifolia Trel., Q. subespatulata Trel., Q. conspersa Benth., Q. elliptica Née and Q. planipocula Trel.), P. oocarpa and to a lesser extent other broadleaved species. 
Tree density in stands 111 and 107 (Table 1), varied from 247.9 to 853.1 respectively, with an average value of $397.6 \pm 25.2$ trees ha 1 . As tree density data were not normally distributed, a Box-Cox transformation was used with parameter -0.95 . This way, tree density transformed data became normal for both vegetation strata (Shapiro-Wilk; $\mathrm{p}=0.42, \mathrm{p}=$ 0.43 respectively), and showed no statistical difference between the tree density transformed population means in pine-oak and oak strata (Levene $=0.26, \mathrm{p}=0.61$; Welch $\mathrm{t}=-1.45, \mathrm{p}=0.16$ ) (Table 2).
The average basal area per stand fluctuated between $16.05 \mathrm{~m}^{2} \mathrm{ha}^{-1}$ in the 081 stand of the Quercus stratum and $27.06 \mathrm{~m}^{2} \mathrm{ha}^{-1}$ in the 052 stand of the Pinus-Quercus one (Table 1); while the average basal area for the microwatershed temperate forest ecosystem was $22.9 \pm 0.9 \mathrm{~m}^{2} \mathrm{ha}^{-1}$ (Table 2). Basal area data from both vegetation strata (P-Q and Q) had normal distribution (Shapiro-Wilk; $\mathrm{p}=0.74, \mathrm{p}=0.22$ respectively), and showed no statistical difference between the population means of basal area of the tree strata (Levene $=2.90, \mathrm{p}=0.10 ;$ Welch $\mathrm{t}=1.92, \mathrm{p}=$ $0.06)$.

Table 1: Average dasometric variables estimated by stand in the temperate forest of the Hueyapa River,

Guerrero, Mexico microwatershed.

\begin{tabular}{|c|c|c|c|c|c|c|c|}
\hline $\begin{array}{l}\text { (Forest) } \\
\text { Stand }\end{array}$ & Vegetation & $\begin{array}{c}\text { Land } \\
\text { Surface } \\
\text { (ha) }\end{array}$ & $\begin{array}{c}\text { Tree } \\
\text { density } \\
\text { (No. of } \\
\text { trees } \\
\text { ha }^{-1} \text { ) }\end{array}$ & $\begin{array}{c}\text { Basal } \\
\text { area } \\
\left(\mathbf{m}^{2} \mathbf{h a}^{-1}\right)\end{array}$ & $\begin{array}{l}\text { Bulk density } \\
\quad\left(\mathrm{gr} \mathrm{cm}^{-3}\right)\end{array}$ & 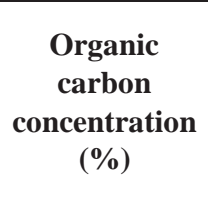 & $\begin{array}{c}\text { SOC by } \\
\text { stand } \\
\left(\mathrm{Mg} \mathrm{ha}^{-1}\right)^{*}\end{array}$ \\
\hline 008 & $P-Q$ & 60.6 & 306.3 & 21.0 & 1.20 & 1.595 & 48.57 \\
\hline 025 & P-Q & 140.9 & 312.7 & 23.2 & 1.19 & 2.175 & 77.43 \\
\hline 027 & P-Q & 112.4 & 381.3 & 22.5 & 1.09 & 2.682 & 79.66 \\
\hline 032 & P-Q & 177.5 & 385.9 & 22.9 & 1.15 & 1.812 & 63.19 \\
\hline 036 & P-Q & 40.0 & 422.9 & 22.8 & 1.15 & 1.595 & 55.19 \\
\hline 043 & P-Q & 66.2 & 343.8 & 23.9 & 1.16 & 2.827 & 81.42 \\
\hline 045 & P-Q & 115.3 & 437.5 & 24.5 & 1.26 & 0.870 & 32.71 \\
\hline 047 & P-Q & 141.56 & 328.1 & 26.6 & 1.24 & 1.957 & 72.51 \\
\hline 052 & P-Q & 108.5 & 281.3 & 27.1 & 1.22 & 1.812 & 66.32 \\
\hline 054 & P-Q & 100.9 & 356.3 & 25.1 & 1.19 & 1.957 & 71.54 \\
\hline 060 & P-Q & 125.3 & 421.9 & 20.2 & 1.20 & 1.885 & 67.86 \\
\hline 062 & P-Q & 150.7 & 400.0 & 18.4 & 1.24 & 1.087 & 40.27 \\
\hline 063 & P-Q & 88.2 & 331.3 & 24.6 & 1.18 & 2.175 & 77.32 \\
\hline 107 & P-Q & 53.6 & 853.1 & 22.7 & 1.14 & 2.827 & 96.68 \\
\hline 108 & P-Q & 45.1 & 409.4 & 24.9 & 1.27 & 2.609 & 84.14 \\
\hline 111 & P-Q & 75.2 & 247.9 & 22.8 & 1.15 & 2.030 & 69.83 \\
\hline 002 & Q & 84.1 & 541.7 & 25.0 & 1.20 & 2.175 & 76.13 \\
\hline 017 & Q & 180.1 & 303.1 & 25.2 & 1.20 & 2.392 & 83.24 \\
\hline 024 & Q & 56.7 & 302.1 & 17.9 & 1.17 & 1.087 & 38.37 \\
\hline 028 & $\mathrm{Q}$ & 57.2 & 360.9 & 26.0 & 1.12 & 2.102 & 70.94 \\
\hline 031 & Q & 54.0 & 479.2 & 16.6 & 1.29 & 1.740 & 67.16 \\
\hline 035 & Q & 54.6 & 447.9 & 22.7 & 1.18 & 1.522 & 53.73 \\
\hline 037 & Q & 92.9 & 404.7 & 23.4 & 1.21 & 1.957 & 69.28 \\
\hline
\end{tabular}




\begin{tabular}{llrlllll}
\hline 051 & $\mathrm{Q}$ & 88.3 & 325.0 & 23.0 & 1.17 & 2.175 & 49.37 \\
061 & $\mathrm{Q}$ & 127.3 & 503.1 & 24.9 & 1.20 & 1.812 & 64.96 \\
071 & $\mathrm{Q}$ & 74.2 & 404.2 & 17.9 & 1.11 & 1.812 & 64.96 \\
072 & $\mathrm{Q}$ & 67.2 & 487.5 & 23.8 & 1.14 & 1.667 & 60.16 \\
076 & $\mathrm{Q}$ & 65.2 & 512.5 & 20.9 & 1.18 & 1.087 & 57.26 \\
081 & $\mathrm{Q}$ & 49.2 & 331.3 & 16.1 & 1.17 & 1.885 & 38.32 \\
084 & $\mathrm{Q}$ & 20.0 & 409.4 & 18.9 & 1.20 & 2.102 & 66.16 \\
085 & $\mathrm{Q}$ & 19.8 & 540.6 & 18.6 & 1.11 & 1.914 & 75.36 \\
105 & $\mathrm{Q}$ & 43.7 & 625.0 & 21.3 & 1.12 & 2.175 & 64.02 \\
106 & $\mathrm{Q}$ & 26.8 & 706.3 & 22.5 & 1.13 & 2.247 & 73.08 \\
\hline
\end{tabular}

$\mathrm{P}-\mathrm{Q}=$ Pinus - Quercus spp. stratum, $\mathrm{Q}=$ Quercus spp. stratum $*$ At $0.30 \mathrm{~m}$ depth

Table 2: Reservoir of the Hueyapa River microwatershed by stratum and temperate forest ecosystem (estimated mean \pm standard error)

\begin{tabular}{|c|c|c|c|c|c|}
\hline & Vegetation & $\begin{array}{c}\text { (Land) Surface } \\
\text { (ha) }\end{array}$ & $\begin{array}{c}T D \text { (No. of trees } \\
\left.\text { ha }^{-1}\right)\end{array}$ & $\begin{array}{c}\text { Basal area } \\
\left(\mathbf{m}^{2} \mathbf{h a}^{-1}\right)\end{array}$ & $\begin{array}{c}\text { SOC } \\
\left(\mathrm{Mg} \mathrm{ha}^{-1}\right)^{*}\end{array}$ \\
\hline & P-Q & $1,601.8$ & $\begin{array}{l}376.2 \\
\pm 35.3\end{array}$ & $\begin{array}{r}23.2 \\
\pm 1.3\end{array}$ & $65.98 \pm 0.90$ \\
\hline \multirow[t]{4}{*}{ Average } & Q & $1,160.1$ & $\begin{array}{l}427.3 \\
\pm 35.2\end{array}$ & $\begin{array}{r}22.4 \\
\pm 1.2\end{array}$ & $64.88 \pm 2.07$ \\
\hline & $\begin{array}{l}\text { Temperate } \\
\text { forest }\end{array}$ & $2,701.9$ & $\begin{array}{l}397.6 \\
\pm 25.2\end{array}$ & $\begin{array}{r}22.9 \\
\pm 0.9\end{array}$ & $65.52 \pm 1.01$ \\
\hline & & $\begin{array}{l}\text { Surface } \\
\text { (ha) }\end{array}$ & $T D$ (No. of trees) & $\begin{array}{l}\text { Basal area } \\
\qquad\left(\mathrm{m}^{2}\right)\end{array}$ & $\begin{array}{l}\mathrm{SOC} \\
(\mathrm{Mg})^{*}\end{array}$ \\
\hline & P-Q & $1,601.819$ & $\begin{array}{l}599,594.3 \\
\pm 56,357.1\end{array}$ & $\begin{array}{c}37,019.3 \\
\pm 2,074.2\end{array}$ & $\begin{array}{c}105,164.7 \pm \\
1,435.0\end{array}$ \\
\hline \multirow[t]{2}{*}{ Total } & Q & $1,160.096$ & $\begin{array}{l}493,516.1 \\
\pm 40,667.2\end{array}$ & $\begin{array}{c}25,884.2 \\
\pm 1,425.9\end{array}$ & $\begin{array}{c}74,937.9 \pm \\
2,388.7\end{array}$ \\
\hline & $\begin{array}{l}\text { Temperate } \\
\text { forest }\end{array}$ & $2,701.915$ & $\begin{array}{l}1,093,110.4 \\
\pm 69,497.8\end{array}$ & $\begin{array}{c}62,903.5 \\
\pm 2,517.0\end{array}$ & $\begin{array}{c}18,0102.6 \pm \\
2,786.6\end{array}$ \\
\hline
\end{tabular}

*At $0.30 \mathrm{~m}$ depth.

Organic carbon in the mineral soil of the Hueyapa River microwatershed

Based on data from INEGI (2015), the primary soils in the temperate forest of the microwatershed are mollic leptosol and, to a lesser extent, epileptic eostric regosol (Figure 2); soils characterized by low depth and incipient development on unbound materials (Galicia et al., 2016). However, in two of the profiles sampled (one for each tree stratum), deep soils
$(>1.80 \mathrm{~m})$ were observed with a $4.0 \mathrm{~cm}$ organic horizon and an A horizon with accumulation of organic matter $(6.0 \mathrm{~cm}$ deep), followed by a reddish-yellowish mineral soil layer (Horizon B) and, subsequently, traces of weathering whitish parental material (granite rock; Horizon C) were found.

The $B d$ of the study area's mineral soil is relatively homogeneous, and ranged from 1.09 to 1.29 , which corresponds to clay and loam 


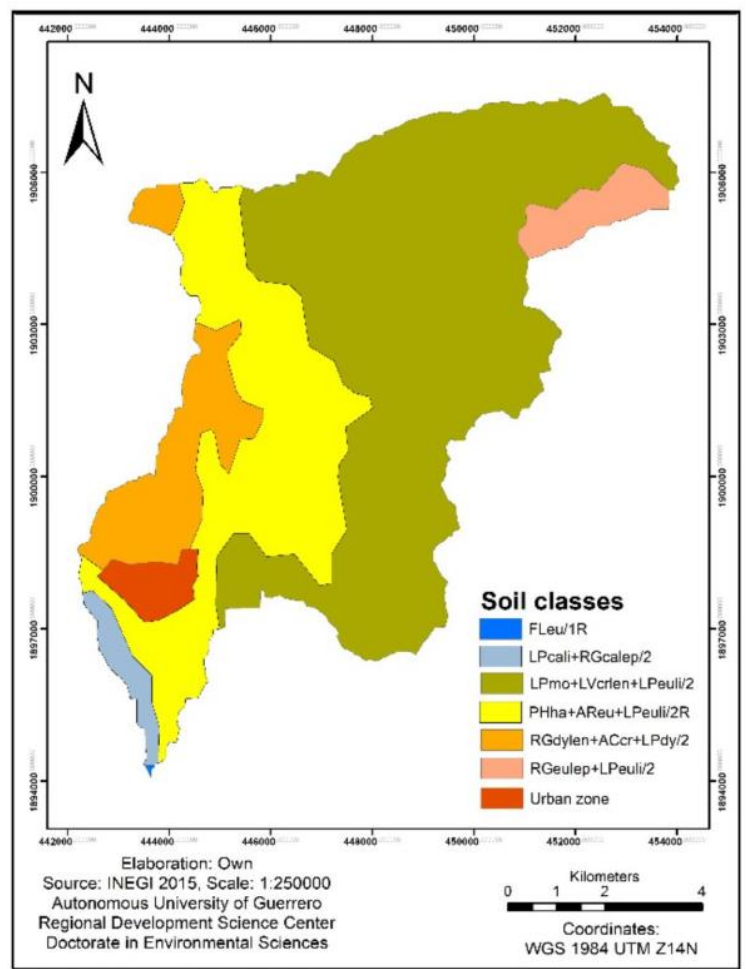

Figure 2: Types of soil in the Hueyapa River microwatershed

textured soils (DOF, 2002). The concentration of organic carbon varied from $0.87 \%$ to 2.83 $\%$. Both $B d$ strata samples data had normal distribution (Shapiro-Wilk; $\mathrm{p}=0.82, \mathrm{p}=$ 0.09 respectively), and showed no statistical difference between the $B d$ population means in pine-oak and oak strata (Levene $=0.11, \mathrm{p}=$ 0.74; Welch $\mathrm{t}=1.13, \mathrm{p}=0.27)$. Concentration of organic carbon strata samples data (P-Q and Q) had normal distribution (Shapiro-Wilk; $\mathrm{p}=0.45$, $\mathrm{p}=0.08$ respectively), and showed no statistical difference between the concentration of organic carbon population means in pine-oak and oak strata (Levene $=1.67, \mathrm{p}=0.21$; Welch $\mathrm{t}=0.72$, $\mathrm{p}=0.47$ ). This finding differs from what was stipulated by Avilés-Hernández et al. (2009) and Coûteaux et al. (1995), since neither toponymy nor plant production made a difference.

The SOC reservoir, in the stands of the temperate forest of the Hueyapa River watershed, within the upper $30 \mathrm{~cm}$, fluctuates between 32.71 y $96.68 \mathrm{Mg} \mathrm{C}^{-1}$ (Table 1, Figure 3). SOC strata samples had normal distribution
(Shapiro-Wilk; $\mathrm{p}=0.58, \mathrm{p}=0.31$ respectively), and showed no statistical difference between the SOC population means in pine-oak stratum and that of oak (Levene $=0.84, \mathrm{p}=0.37$; Welch $\mathrm{t}=0.92, \mathrm{p}=0.37)$. This finding is contrary to what was found by Stendahl et al. (2010) and Rodríguez et al. (2017).

The SOC reservoir, for the Leptosol soils (lithosols and rendzines), of the forest under study coincides with that reported by EtcheversBarra et al. (2019), with densities of $31.83 \mathrm{Mg}$ $\mathrm{C} \mathrm{ha}^{-1}, 43.55 \mathrm{Mg} \mathrm{C}^{-1}$ and $91.33 \mathrm{Mg} \mathrm{C} \mathrm{ha}^{-1}$, for the soil types of Litosol, Luvisol and Rendzina, respectively; while for vegetation types, it was 48.47 $\mathrm{Mg} \mathrm{C}^{-1}, 50.34 \mathrm{Mg} \mathrm{C}^{-1}$ and $62.26 \mathrm{Mg}$ $\mathrm{C} \mathrm{ha}{ }^{-1}$, for oak-pine, oak and pine-oak forests, in the same order; although, slightly lower than those estimated in this investigation.

The average SOC estimation for the microwatershed temperate forest ecosystem was of $65.52 \pm 1.01 \mathrm{Mg} \mathrm{C}^{-1}$ (Table 2), similar to the range (55-65 $\mathrm{Mg} \mathrm{C} \mathrm{ha}^{-1}$ ) that was observed in the 


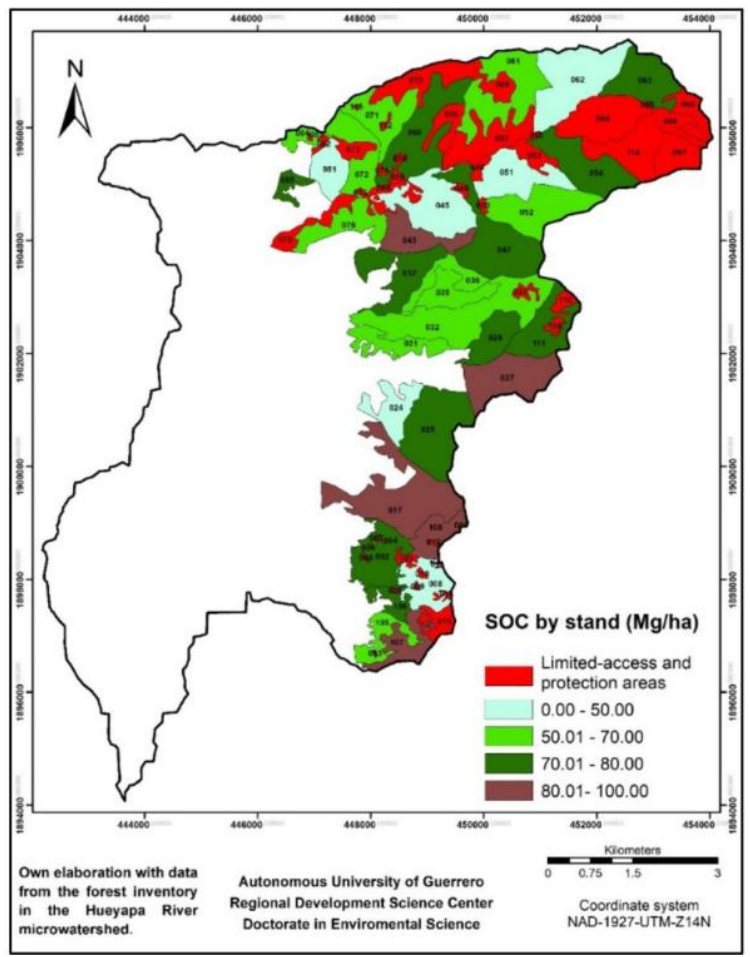

Figure 3: SOC distribution in the temperate forest of the Hueyapa River microwatershed

SOC spatial distribution map, at $30 \mathrm{~cm}$ depth, reported by Paz et al. (2016) for the base year 2007 , for the State of Guerrero and higher than what reported Galicia et al. (2016), for leptosol soils (60 $\left.\mathrm{Mg} \mathrm{ha}^{-1}\right)$ and by Gough et al. (2007) in $35 \mathrm{Mg} \mathrm{C} \mathrm{ha-1} \mathrm{for} \mathrm{forests} \mathrm{near} \mathrm{Lake} \mathrm{Michigan,}$ Michigan, USA.

The SOC average of the microwatershed temperate forest ecosystem under study corresponds to the range reported for soils of pine and other broadleaf forest plantations in the United Kingdom, estimated between 65 y $96 \mathrm{Mg}$ $\mathrm{C} \mathrm{ha}^{-1}$ (Dewar, 1992). Organic carbon density in our study also falls within the range found (59.3 and $66.11 \mathrm{Mg} \mathrm{C} \mathrm{ha}^{-1}$ ) in the volcanic soils of the state of Puebla, Mexico (Valera et al., 2015).

Likewise, González and Candás (2004) estimated SOC between 50 and $60 \mathrm{Mg} \mathrm{C} \mathrm{ha}^{-1}$, in forests of Quercus rotundifolia Lam., which are values slightly lower than those determined for the Quercus spp. stratum $\left(64.88 \pm 2.07 \mathrm{Mg} \mathrm{C}^{-} \mathrm{ha}^{-}\right.$ $\left.{ }^{1}\right)$ in the microwatershed of the Hueyapa River.
From Table 3, the fitted regression model was:

$$
\begin{aligned}
& S \widehat{S C}=-173.900+0.483 T D_{i} \quad+9.896 B A_{i}- \\
& 0.020\left(T D_{i}^{\left.* B A_{i}\right)}\right.
\end{aligned}
$$

The fitted model satisfied the statistical assumptions regarding normal distribution of the errors (Shapiro-Wilk W=0.94, $\mathrm{p}=0.08$ ) and homogeneity of variances (ncvTest $X^{2}=0.63$, $\mathrm{p}=0.43$ ). The independence of the observations is deduced from the fact that the sample was random. The regression model is valid because of the rejection of the global test hypothesis that all three coefficients of the variables equal zero $(F(3,29)=4.66, p=0.01)$, so the relation between SOC and the variables TD, BA y TD*BA is strong. In addition, Table 3 shows that all three parameters were statistically significant at a 0.05 level.

Observation 7 has a studentized residual of -3.5 , which is the largest absolute value but according to the value of the Bonferroni test, it is not an outlier $(p=0.05)$. The values of DFBETAS, DFFITS, Cook's distance and 
Table 3: Parameters and statistics for the model generated to estimate the SOC in the Hueyapa River microwatershed.

\begin{tabular}{lcccc}
\hline \multicolumn{1}{c}{ Variables } & Estimated coefficient & Standard error & T value & Pr $>|\mathbf{t}|$ \\
\hline Intercept & -173.900 & 84.86 & -2.05 & 0.05 \\
$T D$ & 0.483 & 0.22 & 2.27 & 0.03 \\
$B A$ & 9.896 & 3.73 & 2.65 & 0.01 \\
$T D * B A$ & 0.020 & 0.01 & -2.10 & 0.04 \\
\hline
\end{tabular}

$T D=$ Tree density $($ No. of trees ha-1 $),=$ Basal area $\left(\mathrm{m}^{2} \mathrm{ha}^{-1}\right)$

leverages for the most potentially influential observations are shown in Table 4. Last row shows the cut-point for each statistic (Montgomery et al., 2012).

The effect of an observation on the change of an estimated coefficient, measured by the DFBETAS, is within the limit except for observation 7 , but this does not affect other influence statistics. No observation has a Cook's distance greater than 1 which is the cut-off point. Observation 14 has a large leverage () and DFFITS, but since it has a student residual value less than 2 it does not affect the fitting.

The highest correlation between terms in the model was that between TD and TD* BA (0.92). As expected, due to the terms used in the model, there was severe multicollinearity between the terms included in the model (scaled condition number was 164 and VIFs of 165, 25, and 167 of the variables TD, BA and TD*BA).
However, non-reported results show that the model with the three terms TD, BA, and TD * BA is significantly better and it is not possible to eliminate any of the TD or BA variables.

The coefficient of determination was 0.37 , so the fitted model only explained $37 \%$ of the SOC variability. This statistic only measures the goodness of fit of the model to the data and reflects the fact that variables are weakly correlated and there is a lot of noise because data was not obtained from a controlled experiment. The RMSR was 11.47 and the correlation between the predicted and observed COS, that is, its predictive capacity was $r^{2}=0.61$ (Figure 4). Model's prediction, measured with the correlation between predicted and observed SOC, $r^{2}=0.61$, was good although it is lower compared to $\mathrm{r}^{2}=0.90$ obtained by Angst et al. (2018) who included four independent variables in their model.

Table 4: Statistics that measure influence of observations in the fitted regression model

\begin{tabular}{|c|c|c|c|c|c|c|c|}
\hline \multicolumn{8}{|c|}{ DFBETAS } \\
\hline & Intercept & $T D$ & $B A$ & $T D^{*} B A$ & DFFITS & Cook.d & Hat \\
\hline 7 & -0.29 & 0.38 & 0.29 & -0.39 & -0.89 & 0.14 & 0.06 \\
\hline 14 & 0.07 & -0.11 & -0.18 & 0.22 & 1.51 & 0.53 & 0.41 \\
\hline 19 & -0.17 & 0.15 & 0.17 & -0.14 & -0.22 & 0.01 & 0.25 \\
\hline 21 & -0.09 & 0.12 & 0.09 & -0.12 & 0.17 & 0.01 & 0.30 \\
\hline 29 & -0.07 & 0.06 & 0.07 & -0.05 & -0.10 & 0.00 & 0.30 \\
\hline \multirow[t]{2}{*}{31} & -0.12 & 0.14 & 0.12 & -0.14 & 0.17 & 0.01 & 0.29 \\
\hline & & $>\frac{2}{\sqrt{n}}$ & .35 & & $\geq 2 \sqrt{\frac{p}{n}}=0.70$ & 1 & \\
\hline
\end{tabular}




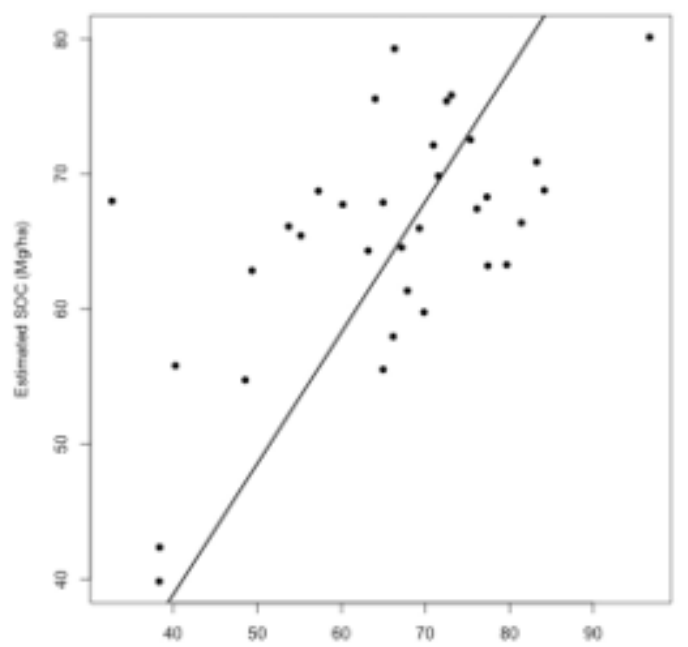

Figure 4: Correlation between the observed SOC and the estimated SOC

\section{Soil fertility of the Hueyapa River microwatershed}

Table 5 summarizes the fertility characteristics of the soil samples from the study area, variable means, and fertility classification based on NOM-021-SEMARNAT-2000 (Diario Oficial de la Federación [D. O. F.], 2002). The high average content of organic matter $(4.0 \%)$, as an indicator of the physical condition of the soil, suggests that they are not threatened by forest degradation (Vergara-Sánchez et al. 2005) and, this is directly related to the high content of SOC.

$\mathrm{pH}$ of the mineral soil at the Hueyapa River microwatershed fluctuated between 4.1 and 4.5 (strongly acidic), a range corresponding to most temperate forest soils as a result of the release of organic acids by the decomposition of the litter and leaching of the surface mineral soil bases (Pritchett, 1991). The acidic pH favors the availability of soluble phosphorus, which encourages the development of cold temperate forest species, such as those found in the Hueyapa microwatershed; however, these $\mathrm{pH}$ values generally prevent agricultural crops from establishment (Moran et al., 2000).

The range of $\mathrm{P}$ found in the microwatershed varies, according to NOM-
021-SEMARNAT-2000 (D. O. F., 2000), from low to high, since six values are lower than 15 ppm, three values are between 15 and $30 \mathrm{ppm}$ (medium level of $\mathrm{P}$ ), and one value is above 30 ppm. Nine out of ten sampled areas coincide with Bray phosphorus values corresponding to soils from basalt parental material (7.7 $23.2 \mathrm{ppm}$ ), while one stand registered $93 \mathrm{ppm}$, coinciding with soils of sandstone parental material (Pritchett, 1991).

The lowest phosphorus concentration (7.7 ppm) in the mineral soils was found in the P-Q stratum with South aspect in the Dos Caminos gorge. The highest value (93 ppm) was registered in the North aspect slope of the P-Q stratum in the La Haciendita gorge. The average phosphorus concentration found is high compared to the $1 \mathrm{ppm}$ reported for the forest soils of the Amazon (Legout et al., 2014), but belongs to the medium range defined by SEMARNAT (D. O. F., 2000).

The average total nitrogen concentration was low $(0.084 \%)$. In fact, it was even lower than that reported by Vergara-Sánchez et al. (2005) on three hillside areas of the Northern highlands of Oaxaca, Mexico. This suggests that application of $\mathrm{N}$ on these sites should result in improved forest productivity, especially 
Table 5: Chemical properties of soils of the Hueyapa River microwatershed 
if this practice takes place during the early development stages of commercial tree species (pine and oak), as suggested by Combatt, Martínez, and Polo (2005) for species with agroforestry potential in the Caribbean region in Córdoba, Colombia.

Cation exchange capacity (CEC) was 5.1 $\mathrm{cmol} \mathrm{kg} \mathrm{g}^{-1}$ in average. This value is indicative of the low availability and exchange of nutrients for plant growth and microbial activity (Thiers, Reyes, Gerding, \& Schlatter, 2014). Even though these soils are red ones with high clay content, whose particles actively participate in ion and water exchange, availabilities of nitrogen and phosphorus were also low and low-medium, respectively. Likewise, the average sum of exchangeable bases $(\mathrm{Ca}, \mathrm{K}, \mathrm{Mg}$ ) was low (5.1

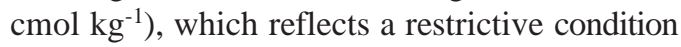
for forest production (Vergara-Sánchez et al., 2005). Therefore, correction of deficiencies of these nutrients should improve vegetation growth and productivity.

Although the CEC in this study was low, compared to that obtained for soils of the forest protection forest reserve of the Hydroelectric Power Plant in Caldas, Colombia $(>15.7 \mathrm{cmol}$ $\mathrm{kg}^{-1}$ ) (Echeverri, Estévez, \& Bedoya, 2014), the availability of exchangeable bases was similar in both studies.

Not always there exists a positive correlation between phosphorus availability and phosphorus concentrations in forest soils, since the biological component (microbial activity) plays an important role in this availability (Legout et al., 2014).

Decreasing $\mathrm{pH}$ values increases the availability of micronutrients such as boron, manganese, copper and iron (Pritchett, 1991), which, with the exception of boron, show adequate concentrations across the entire study area. This disagrees with the generalized low fertility of forest soils referred to by Legout et al. (2014).

Despite the low CEC and nitrogen concentrations in the soils of the Hueyapa River microwatershed, a vigorous and uniform distribution of tree, shrub and herbaceous vegetation is observed in the study area, expressed in terms of tree density and basal area. This is consistent with the availability of phosphorus (medium) and micronutrients (adequate) throughout the study area, as was also observed by Soares da Silva et al. (2017) in the homogeneous distribution of the natural regeneration of forest species in the umbilophilic forests of Pernambuco, Brazil.

\section{Conclusion}

The temperate forest of the Hueyapa River microwatershed shows a tree density high enough to maintain a high organic carbon reservoir in the forest soil. Fertility indicators reflect that they do not show visible forest degradation threats and provide reliable data to support management practices such as chemical fertilization to increase their forest productivity. The SOC reservoir can be estimated with the statistical model developed in this study, which considered tree density and basal area as the independent variables with a good predictive capacity.

These results suggest a need for measuring the processes of litter mineralization, SOC stabilization and the potential net carbon mineralization rate in the temperate forest of the Hueyapa River microwatershed.

\section{Acknowledgements}

To the National Council of Science and Technology (CONACyT) for the financing of the project of the sectoral environmental research fund CONACyT-SEMARNAT key 278639. To the ejidale and municipal authorities of the agrarian community Dos Caminos and Annexes. The results of this project are part of the Doctoral Thesis of the first author, who thanks the Agricultural Technological and Marine Sciences Upper Middle Education Unit (UEMSTAyCM) in the granting of the Scholarship-Commission.

\section{References}

Allison, L. E. (1965). Organic carbon. In C. A. Black, D. D. Evans, J. L. Whit, L. E. 
Ensminger, F. E., \& F. E. Clark (Eds.), Methods of soil analysis (pp. 1372-1378). Madison, Wisconsin, USA: American Society of Agronomy.

Alvarado, J., Andrade, H. J., \& Segura, M. (2013). Almacenamiento de carbono orgánico en suelos en sistemas de producción de café (Coffe arabica L.) en el municipio de Líbano, Tolima, Colombia. Colombia Forestal, 16(1), 21-31

Andrade, H. J., \& Ibrahim, M. (2003). ¿Cómo monitorear el secuestro de carbono en los sistemas silvopastoriles? Agroforestería en la Américas, 10(39-40), 109-116.

Angst, G., Messinger, J., Greiner. M., Häusler, W., Hertel, D., Kirfel, K.,..., Mueller, C.

W. (2018). Soil organic carbon stocks in topsoil and subsoil controlled by parent material, carbon input in the rhizosphere, and microbial-derived compounds. Soil Biology and Biochemestry, 122, 19-30. doi:10.1016/j.soilbio.2018.03.026

Avilés-Hernández, V., Velázquez-Martínez, A., Angeles-Pérez, Etchevers-Barra, G. J., De los Santos-Posadas, H., \& Llanderal, T. (2009). Variación en almacenes de carbono en suelos de una toposecuencia. Agrociencia, 43(5), 457-464.

Berger, K. C., \& Truog, E. (1944). Boron test and determination for soil and plants. Soil Science, 57(1), 25-36. doi: 10.1097/00010694-194401000-0000

Bianchi, S. R., Miyazawa, M., de Oliveira, E. L., \& Pavan, M. A. (2008). Relationship between the mass of organic matter and carbon soil. Brazilian Archives of Biology and Technology, 51(2), 263-269.

Casiano-Domínguez, M., Paz-Pellat, F., RojoMartínez, M., Covaleda-Ocanon, S., \& Raj A., D. El carbono de la biomasa aérea medido en cronosecuencias: Primera estimación en México. Madera y Bosques, 24(Número especial), e2401894. doi:10.21829/myb.2018.2401894

Combatt, E. M., Martínez, G., \& Polo, J. (2005). Caracterización química y física de los suelos agroforestales de la zona alta de Córdoba. Temas Agrarios, 10(2); 5-14.

Comisión Nacional Forestal - Secretaría de Medio Ambiente y Recursos Naturales (CONAFOR-SEMARNAT).

(2011).

Inventario Nacional Forestal y de Suelos. Manual y procedimiento para el inventario de campo. Re-muestreo 2011. Zapopan, Jalisco, México: Autor.

Coûteaux, M.-M., Bottner, P., \& Berg, B. (1995). Litter decomposition, climate and litter quality. Tree, 10(2), 63-66.

Covaleda, S., Paz, F., \& de Jong, B. (2013). Parametrización de modelos de estados y transiciones para el carbono y caracterización de la incertidumbre. pp. 2934. En: F. Paz, M. Bazan y V. Saynes (Eds.). Dinámica del Carbono en el Suelo 2012. Serie Avances Temáticos del Ciclo del Carbono y sus Interacciones. Programa Mexicano del Carbono en colaboración con la Sociedad Mexicana de Ciencias del Suelo. Texcoco, Estado de México, México.

Dewar, R. C. (1992). Carbon sequestration in the trees, products and soil of forest plantation: An analysis using UK example. Tree Physiology, 11, 49-71. doi: 10.1093/ treephys/11.1.49

Diario Oficial de la Federación (D. O. F.). (2002). Norma Oficial Mexicana NOM021-SEMARNAT-2000 que establece las especificaciones de fertilidad, salinidad y clasificación de suelos, estudio, muestreo y análisis. México, D. F.

Echeverri T., L., Estévez V., J. V., \& Bedoya P., J. G. (2014). Caracterización física, química y mineralógica de suelos con vocación forestal protectora, Región Andina Central Colombia. Revista Facultad Nacional de Agronomía-Medellín, 67(2); 7335-7343.

Etchevers-Barra, J. D., Hidalgo-Moreno, C. I., Bolaños-González, M., de Jong, B., Covela-Ocón, M., Fuentes-Ponce, M.,... ,Vargas, R. (2019). Suelos. En: Paz-Pellat, F., J. M. Hernández-Rayón, R. Sosa-Ávalos y A. S. Velázquez-Rodríguez (Eds.). 2019. 
Estado del Ciclo del Carbono: Agenda azul y verde. Programa Mexicano del Carbono. Texcoco, Estado de México, México. 716 p.

Food Agriculture Organization (FAO). (2017). Soil Organic Carbon: The hidden potential. Rome, Italy: Food and Agriculture Organization of the United Nations.

Fox, J. (2016). Applied regression analysis and generalized linear models (3rd ed.) London, UK: SAGE Publications, Inc. p. 674-677.

Fox, J., \& S. Weisberg. (2011). An $\{R\}$ Companion to Applied Regression, Second Edition. Thousand Oaks CA: Sage. Recuperado de URL: http://socserv.socsci. mcmaster.ca/jfox/Books/ Companion

Galicia, L., Gamboa C., A. M., Cram, S., Chávez V., B., Peña R., V., Saynes, V., \& Siebe, C. (2016). Almacén y dinámica del carbono orgánico del suelo en bosques templados de México. Terra Latinoamericana 34(1), $1-29$.

González, D., Almendros, P., \& Álvarez, J. M. (2009). Métodos de análisis de elementos en suelos: disponibilidad y fraccionamiento. An. Quím., 105(3), 205-212.

González, P. J., \& Candás, V. Ma. A. (2004). Materia orgánica de suelos bajo encinas. Mineralización de carbono y nitrógeno. Investigación Agraria: Sistemas y Recursos Forestales, 13(4), 75-83.

Gough, C. M., Vogel, C. S., Harrold. K. H., Goerge, K., \& Curtis, P. S. (2007). The legacy oy harvest and fine on ecosystem carbon storage in a north temperate forest. Global change Biology, 13(9), 1935-1949. doi: 10.1111/j.1365-2486.2007.01406.x

Gross, J., \& U. Ligges. (2015). Nortest: Tests for normality. R package versión 1.0-4. Recuperado de https://CRAN.R-project. org $/$ package $=$ nortest

Instituto Nacional de Estadística y Geografía (INEGI). (2010). Documento técnico descriptivo de la Red Hidrográfica escala 1:50000 edición 2.0. Aguascalientes, México: Autor Obtenido de http://antares. inegi.org.mx/analisis/ red_hidro/PDF/Doc. pdf

IPCC (Intergovernmental Panel on Climate Change). (2006). 2006 IPCC Guidelines for National Greenhouse Gas Inventories, Prepared by the National Greenhouse Gas Inventories Programme. In Eggleston, H. S., Buendia, L., Miwa K., Ngara T., \& Tanabe K. (Eds). Publicado por: IGES, Japón.

Kalra, Y. P., \& Maynard, D. G. (1991). Methods manual for forst soil and plant analysis. Edmonton, Alaberta, Canada: Forest Canadian, Northwest Region, Northern Forestry Center. $116 \mathrm{p}$.

Legout, A., Hansson, K., Van Der Heijden, G., Laclau, J. P., Augusto, L., \& Ranger, J. (2014). Chemical fertility of forest soil: Basic concepts. Rev. For. Fr., 66, 21-31.

McLeod, S. (1973). Studies on wet oxidation procedures for the determination of organic carbon in soil. CSIRO Division of Soil, Notes on Soil Techniques. pp. 73-79.

Monreal, C. M., Etchevers, J. D., Acosta, M., Hidalgo, C., Padilla, J., López, R. M., Jiménez, L., \& Velázquez, A. (2005). A method for measuring above- and belowground C stocks in hillside landscapes. Canada Jurnal Soil Science 85, 523-530.

Montgomery, D. C., Peck, E. A., \& Vining, G. G. (2012). Introduction to linear regression analysis (5th ed.). New Jersey, EUA: John Wiley \& Sons, Inc.

Moran, E. F., Brondizio, E. S., Tucker, J. M., da Silva-Forsberg, M. C., McCracken, S., \& Falesi, I. (2000). Effects of soil fertility and land-use on forest succession in Amazônia. Forest Ecology and Management, 139(13), 93-108. doi:10.1016/s03781127(99)00337-0

Navarro-Martínez, J., Reyes-Umaña, M., Rosas-Acevedo, J. L., Juárez-López, A. L., López-López, M. A., \& Godínez-Jaimes, F. (2019). Morphometric characterization of the Hueyapa river microwatershed, in Guerrero, México. International Journal 
of Applied Environmental Sciences 14(4), 351-366.

Pan, Y., Birdsey, R. A., Fang, J., Houghton, R., Kauppi, P. E., Kurz, W. A.,..., Hayes, D. (2011). A large and persistent carbon sink in the world's forests. Science 333, 988-993.

Pan, Y., Birdsey, R. A., Phillips, O. L., \& Jackson, R. B. (2013). The structure, distributions and biomass of the world's forests. Annual Review of Ecology, Evolution, and Systematics 44, 593-622. doi:10.1146/ annurev-ecolsys-110512-135914

Paz, F., \& Etchevers, J. (2016). Distribución a profundidad del carbono orgánico en los suelos de México. Terra Latinoamericana, 34, 339-355.

Paz, P.F.,Argumedo, E. J., Cruz, G. O., Etchevers, D. J., \& de Jong, B. (2016). Distribución especial y temporal del carbon orgánico del suelo en los ecosistemas terrestres de México. Terra Latinoamericana, 34(3), 289-310.

Post, W. M., \& Kwon, K. C. (2000). Soil carbon sequestratio and land-use change: Processes and potential. Global Change Biology, 6, 317-328.

Pribyl, D. W. (2010). A critical review of the conventional SOC to SOM conversión factor. Geoderma, 156(3-4), 75-83. doi: 10.1016/j.geoderma.2010.02.003

Pritchett, W. L. (1991). Suelos forestales (1 ${ }^{\mathrm{a}}$. ed.). México: LIMUSA.

Quinto M., H., Moreno H., F., Caicedo M., H. Y., \& Perez L., M. T. (2016). Biomasa de Raíces Finas y Fertilidad del Suelo en Bosques Pluviales Tropicales del Pacífico Colombiano. Colombia Forestal, 19(1), 5366. doi:10.14483/udistrital.jour.colomb. for.2016.1.a04

R Core Team. (2016). R: A language and environment for statistical computing. $\mathrm{R}$ Foundation for Statistical Computing, Vienna, Austria. Available from URL https://www.R-project.org/
Rodríguez, R. M., Yunta, M. F., Guirado, T. M., Ortega, M. A., Cuevas, R. J., \& Gumuzzio, F. J. (2017). Carbono orgánico en suelos forestales del Principado de Asturias: importancia de los horizontes subsuperficiales e influencia de la fisionomía de la cubierta vegetal. $7^{\circ}$ Congreso Forestal Español. Sociedad Española de Ciencias Forestales (Ed.), Plasencia, Cáceres, España.

Ross, S. M. (2005). Introducción a la estadística. Barcelona, España: Reverté.

Salcedo-Pérez, E., Ruiz, B. B. A., HernándezÁlvarez, E., González, C. R., BernabéAntonio, A., Orozco-Guareño, E.,..., Delgado-Fornué, E. (2019). Soil properties and nitrogen as indicators of growth in teak commercial stand. Revista Mexicana de Ciencias Forestales, 10(52), 33-54. doi:10.29298/rmcf.v10i52.398

Soares da Silva, R. K., Patriota F., A. L., Morangon, L. C., dos Santos F., B. G., Freire, F. J., de Andrade F., R. B.,...,Fortes da Silva, A. C. (2017). Soil fertility as a predictor of the geospatial distribution of forest species in natural regeneration in Brazil. Journal of Experimental Agriculture International, 19(4), 1-18. doi:10.9734/ JEAI/2017/38652

Stendahl, J., Johansson, M. B., Eriksson, E., Nilsson, A., \& Langvall, O. (2010). Soil organic carbon in Swedish spruce and pine forests - differences in stock levels and regional patterns. Silva Fennica, 44(1), 521.

Thiers, O., Reyes, J., Gerding, V., \& Schalatter, J. E. (2014). Suelos en ecosistemas forestales. In: C. Donoso, M. E. González, A. Lara (Eds.), Ecología forestal. Bases para el manejo sustentable y conservación de los bosques nativos de Chile (pp. 133178). Valdivia, Chile: Ediciones UACh.

Thongjoo, C., Choosak, S., \& Chaichana, R. (2018). Soil fertility improvement from commercial monospecific mangrove forests (Rhizophora apiculata) at Yeesarn Village, 
Samut Songkram Province, Thailand. Tropical Ecology, 59(1), 91-97.

Valera, P. M. A., Ríos, P. A., Coyotl, T. A., Linares, F. G., Tenorio, A. M. G., \& Sampedro, R. M. L. (2015). El suelo como almacén de carbono: Criterios para calidad de carbono secuestrado en suelos. Revista Latinoamericana el Ambiente y las Ciencias, 6(11), 44-55.

Velasco, B. E., Ramírez, M. H., Moreno, S. F., \& de la Rosa, V. A. (2003). Estimadores de razón para el inventario nacional forestal de México. Rev. Ciencias Forestales en México, 28(94), 23-43.
Venables, W. N., \& Ripley, B. D. (2002). Modern applied statistics with $S$ (4th ed.). New York. ISBN 0-387-95457-0.

Vergara-Sánchez, M. A., Etchevers-Barra, J. D., \& Padill-Cuevas, J. (2005). Fertilidad de los suelos de ladera de la sierra norte de Oaxana, México. Agrociencia, 39(3), 59266.

Walkley, A., \& Black, I. A. (1934). An examination of the Degtjareff method for determining soil organic matter, and a proposed modification of the chromic soil titration method. Soil Science, 37(1), 29-38. doi: 10.1097/00010694-193401000-00003 